\title{
LACK OF GONADOTROPHIN-INHIBITING ACTIVITY OF OVINE PINEAL EXTRACTS
}

\author{
L. DEBELJUK \\ Centro de Investigaciones sobre Reproducción, Facultad de Medicina, \\ Universidad de Buenos Aires, Buenos Aires, Argentina
}

(Received 31st March 1970)

Several investigators have reported that defatted pineal extracts exert inhibitory effects on the secretion and activity of adenohypophysial gonadotrophins. Moszkowska (1965) found that such extracts inhibited the release of gonadotrophins by the adenohypophysis in vitro and Soffer, Vogel \& Rudavsky (1965) reported that these extracts abolished the stimulatory effect of HCG and HMG on the uterine weight of the female rat. It has also been reported (Thieblot, Alassimone \& Blaise, 1966) that defatted pineal extracts produce a decrease in the pituitary gonadotrophin activity of castrated male rats. Other authors, however, have observed contradictory effects with crude extracts, which have been interpreted as indicating the presence of stimulatory and inhibitory factors (Reiss, Davis, Sideman, Mauer \& Plichta, 1963). On the other hand, Prop \& Ebels (1968) did not observe any effect of total pineal extracts on the reproductive system of either the male or the female rat and recorded nuclear changes only in the pineal cells of the injected animals.

It seemed of interest, therefore, to re-investigate the action of defatted pineal extracts on the reproductive organs and the pituitary LH content of the male rat. The pineal extract was prepared from young sheep pineals. The glands were homogenized and defatted through several changes of acetone. The insoluble precipitate was then suspended in distilled water, heated to $60^{\circ} \mathrm{G}$ for $4 \mathrm{hr}$ in order to inactivate enzymatic activity, and centrifuged. The supernatant was freeze-dried and divided into small fractions. It should be pointed out that, due to the extraction with acetone, this extract is probably devoid of melatonin, the indolic substance synthesized by the pineal gland (Thieblot, Blaise \& Couquelet, 1967). The extract was appropriately diluted with distilled water before administration to 26 -day-old male Wistar rats. They were injected subcutaneously with a daily dose of the pineal extract equivalent to $5 \cdot 3$ ovine pineal glands per rat. The treatment lasted 30 days. A group of control rats were injected with distilled water for the same period. The animals were killed at the end of the treatment period and the wet weights of adenohypophyses, testes, seminal vesicles and ventral prostates were recorded. The anterior pituitary glands were then quickly homogenized and frozen. The pituitary LH activity was determined according to the method of Parlow (1961). The 
significance of the differences between groups was tested by means of Student's $t$ test.

The results presented in Table 1 and Table 2 clearly show that the administration of ovine pineal extracts does not produce changes in the weight of the sexual structures or in the pituitary LH concentration. Thus, the results presented here disagree with the data of other authors who used similar extracts

TABLE 1

EFFEGT OF THE TREATMENT WITH OVINE PINEAL EXTRAGTS IN MALE RATS

\begin{tabular}{c|c|c|c|c|c}
\hline \multicolumn{1}{c|}{ Treatment } & $\begin{array}{c}\text { Final body } \\
\text { weight }(g)\end{array}$ & $\begin{array}{c}\text { Anterior } \\
\text { pituitary } \\
\text { weight }(\mathrm{mg})\end{array}$ & $\begin{array}{c}\text { Testicular } \\
\text { weight }(\mathrm{g})\end{array}$ & $\begin{array}{c}\text { Seminal } \\
\text { vesicles } \\
\text { weight }(\mathrm{mg})\end{array}$ & $\begin{array}{c}\text { Ventral } \\
\text { prostate } \\
\text { weight }(\mathrm{mg})\end{array}$ \\
\hline $\begin{array}{c}\text { Controls (16)* } \\
\begin{array}{c}\text { Ovine pineal } \\
\text { extracts (16) }\end{array}\end{array}$ & $108 \cdot 5 \pm 2 \cdot 89$ & $3 \cdot 48 \pm 0 \cdot 14$ & $0.999 \pm 0.062$ & $51 \cdot 0 \pm 10 \cdot 0$ & $42 \cdot 3 \pm 4 \cdot 86$ \\
\hline
\end{tabular}

Values are means \pm S.E.

* Number of animals in parentheses.

TABLE 2

EFFEGT OF THE TREATMENT WITH OVINE PINEAL EXTRAGTS ON ADENOHYPOPHYSIAL LH ACTIVITY IN MALE RATS

\begin{tabular}{|c|c|c|c|c|c|}
\hline Treatment & $\begin{array}{c}\text { Dose of } \\
\text { anterior } \\
\text { pituitary } \\
(m g)^{*}\end{array}$ & $\begin{array}{c}\text { Ovarian } \\
\text { ascorbic acid } \\
\text { concentration } \\
(\mu g / 100 \mathrm{mg} \pm S . E .)\end{array}$ & $\begin{array}{l}\text { Pituitary } L H \\
\text { concentration } \dagger\end{array}$ & $\begin{array}{l}95 \% \text { Confidence } \\
\text { limits }\end{array}$ & $\lambda$ \\
\hline Controls & $\begin{array}{l}0 \cdot 1 \\
0.4\end{array}$ & $\begin{array}{l}72 \cdot 8 \pm 2 \cdot 43 \\
51 \cdot 8 \pm 2 \cdot 00\end{array}$ & $6 \cdot 18$ & 5.02 to 7.37 & $0 \cdot 14$ \\
\hline $\begin{array}{l}\text { Ovine pineal } \\
\text { extracts }\end{array}$ & $\begin{array}{l}0.1 \\
0.4\end{array}$ & $\begin{array}{l}69 \cdot 6 \pm 2 \cdot 83 \\
50 \cdot 0 \pm 5 \cdot 04\end{array}$ & $7 \cdot 34$ & 5.44 to 9.79 & 0.22 \\
\hline
\end{tabular}

* Six to seven animals per group were used.

$\dagger$ Expressed as $\mu$ g-equiv. NHH-LH-s12/mg wet weight of anterior pituitary gland.

(Soffer et al., 1965; Thieblot et al., 1966). It remains to be demonstrated, however, whether lipid pineal extracts have an inhibitory activity on pituitary gonadotrophins.

This work was supported by The Population Council, Inc., New York. The constant support of Professor R. E. Mancini is gratefully acknowledged. Thanks are also due to O. A. Paulucci and V. M. Feder for their excellent technical assistance, to Frigorífico CAP Lisandro de la Torre, Buenos Aires, for having collected the ovine pineal glands, and to National Institutes of Health, Bethesda, Maryland, for the gift of the standards used in the LH bioassays.

\section{REFERENCES}

Moszkowska, A. (1965) Contributions a l'étude du mécanisme de l'antagonisme epiphyso-hypophysaire. Prog. Brain Res. 10, 564.

Parlow, A. F. (1961) In: Human Pituitary Gonadotropins, p. 300. Ed. A. Albert. Charles C. Thomas, Springfield, Ill. 
Prop, N. \& Ebers, I. (1968) Effects of sheep and young calf pineal extracts and continuous light on the pineal glands, the gonads and the oestrous cycle of the rat. Acta endocr., Copenh. 57, 585.

Reiss, M., Davis, R. H., Sideman, M. B., Mauer, I. \& Plichta, E. S. (1963) Action of pineal extracts on the gonad and their function. F. Endocr. 27, 107.

SOFFER, L., VOGEL, M. \& RUdAvsky, A. (1965) The presence of a "gonadotropin inhibiting substance" in pineal gland extracts. Acta endocr., Copenh. 48, 561.

Thieblot, L., Alassimone, A. \& Blaise, S. (1966) Etude chromatographique et electrophorétique du facteur antigonadotrope de la glande pinéale. Annls Endocr. 27, 861.

Theblot, L., Blaise, S. \& Couguelet, J. (1967) Recherche de dérivés indoliques dans des extracts de glande pinéale. C. r. Séanc. Soc. Biol. 161, 295. 